OPEN ACCESS

Edited by:

Gloria Soberón-Chávez,

National Autonomous University

of Mexico, Mexico

Reviewed by:

Jonas Contiero,

São Paulo State University, Campus

Rio Claro, Brazil

Vivek Sharma,

Chandigarh University, India

${ }^{*}$ Correspondence:

Stéphan Dorey

stephan.dorey@univ-reims.fr

${ }^{\dagger}$ These authors have contributed equally to this work

Specialty section:

This article was submitted to

Industrial Biotechnology,

a section of the journal

Frontiers in Bioengineering and

Biotechnology

Received: 24 May 2020

Accepted: 03 August 2020

Published: 08 September 2020

Citation:

Crouzet J, Arguelles-Arias A, Dhondt-Cordelier S, Cordelier S,

Pršić J, Hoff G,

Mazeyrat-Gourbeyre $F$, Baillieul $F$, Clément $C$, Ongena $M$ and Dorey $S$

(2020) Biosurfactants in Plant

Protection Against Diseases:

Rhamnolipids and Lipopeptides Case

Study.

Front. Bioeng. Biotechnol. 8:1014. doi: 10.3389/fbioe.2020.01014

\section{Biosurfactants in Plant Protection Against Diseases: Rhamnolipids and Lipopeptides Case Study}

\author{
Jérôme Crouzet ${ }^{1 \dagger}$, Anthony Arguelles-Arias ${ }^{2 \dagger}$, Sandrine Dhondt-Cordelier ${ }^{1 t}$, \\ Sylvain Cordelier ${ }^{1+}$, Jelena Pršić2 ${ }^{2}$, Gregory Hoff ${ }^{2}$, Florence Mazeyrat-Gourbeyre', \\ Fabienne Baillieul' ${ }^{1}$, Christophe Clément ${ }^{1}$, Marc Ongena ${ }^{2 \dagger}$ and Stéphan Dorey ${ }^{1 *+}$ \\ ${ }^{1}$ Unité RIBP EA 4707, SFR Condorcet FR CNRS 3417, University of Reims Champagne-Ardenne, Reims, France, ${ }^{2}$ MiPI \\ Laboratory, Gembloux Agro-Bio Tech, SFR Condorcet FR CNRS 3417, University of Liège, Gembloux, Belgium
}

Biosurfactants are amphiphilic surface-active molecules that are produced by a variety of microorganisms including fungi and bacteria. Pseudomonas, Burkholderia, and Bacillus species are known to secrete rhamnolipids and lipopeptides that are used in a wide range of industrial applications. Recently, these compounds have been studied in a context of plant-microbe interactions. This mini-review describes the direct antimicrobial activities of these compounds against plant pathogens. We also provide the current knowledge on how rhamnolipids and lipopeptides stimulate the plant immune system leading to plant resistance to phytopathogens. Given their low toxicity, high biodegradability and ecological acceptance, we discuss the possible role of these biosurfactants as alternative strategies to reduce or even replace pesticide use in agriculture.

Keywords: rhamnolipids, lipopeptides, antimicrobial, plant immunity, elicitor, plant pathogen

\section{INTRODUCTION}

Plant pathogens cause significant agricultural damages ranging from 10 to $40 \%$ depending on the crops before or after harvest, resulting in huge economic losses (Savary et al., 2019). Diseases and pests are therefore major problems for sustainable agriculture in the world. Chemical pesticides are largely used to control plant disease worldwide (Popp et al., 2013). However, chemical pesticides can be detrimental to human and environmental health and therefore, development and optimization of alternative strategies to reduce their utilization for crop protection is becoming a necessity. Biocontrol is a promising strategy based on the use of organisms that decrease disease pressure by competing with the pathogen for space and nutrients, by inducing the plant's natural defense system, and/or by the production of antimicrobial substances (Berg et al., 2017; Bonanomi et al., 2018; Syed Ab Rahman et al., 2018). In addition, natural, ecofriendly and biodegradable compounds isolated from (micro)organisms can also be part of a biocontrol strategy. These compounds can act directly onto the pathogen via antimicrobial properties or by stimulating the plant immune system to prime plant protection against disease (Delaunois et al., 2014; Bardin et al., 2015; Keswani et al., 2019). Molecules from microbial origin stimulating the plant immune system are called invasion patterns or elicitors and are highly diverse both in nature and origins (Vatsa et al., 2010; Delaunois et al., 2014; Burketova et al., 2015; Schellenberger et al., 2019).

The main classes of microbial biosurfactants are represented by mannosylerythritol lipids (MEL), trehalose dimycolate (TDM), trehalolipids, sophorolipids, rhamnolipids and lipopeptides. 
They are used in detergent and cleaning solutions and display a very wide range of applications such as food industry, soil and water remediation, microbial enhanced oil recovery, biomedical science, cosmetic industry, nanotechnology and agriculture (Naughton et al., 2019; Singh et al., 2019). They have been studied since decades in biomedical sciences, especially for their antimicrobial properties and as modulators of human innate immunity [for extensive reviews see Singh and Cameotra (2004), Banat et al. (2010), Vatsa et al. (2010), Naughton et al. (2019), Coelho et al. (2020), Jahan et al. (2020), Sajid et al. (2020)]. Some of these microbial biosurfactants exhibit antimicrobial properties that are effective against a large panel of plant pathogens (Mnif and Ghribi, 2016; Penha et al., 2020). In addition, rhamnolipids and lipopeptides have been shown to stimulate the plant immune system conferring a better resistance to fungal and bacterial pathogens (D'aes et al., 2010; Raaijmakers et al., 2010; Vatsa et al., 2010; Schellenberger et al., 2019). In this review, we will provide current knowledge and recent advances on the role of biosurfactants in plant protection. We will focus on rhamnolipids and lipopeptides since these biosurfactants are the most studied for agricultural applications and are among the most effective and economically profitable for industrial production.

\section{BIOSURFACTANTS AS BIOPESTICIDES}

The main interest in the use of biosurfactants as biopesticides in disease management is their environmental-friendly characteristics, high biodegradability and production from renewal energy resources. Rhamnolipids and lipopeptides have been extensively studied in the context of crop protection. Conversely, other biosurfactants such as sophorolipids, MEL and cellobiose lipids have marginally been investigated for their antimicrobial properties toward plant pathogens (Yoshida et al., 2015; Mnif and Ghribi, 2016; Sen et al., 2017; Chen et al., 2020; Penha et al., 2020). Because rhamnolipids and lipopeptides display a good balance between industrial production, efficacy and preservation of the environment, they are very interesting candidates in biocontrol strategies.

\section{Rhamnolipids Are Efficient Bio-Fungicides}

Rhamnolipids are glycolipids produced by various bacterial species including some Pseudomonas sp. and Burkholderia sp. (Abdel-Mawgoud et al., 2010). Whereas no direct or robust evidences have been reported for rhamnolipid antibacterial or antiviral activities against plant pathogens, a large number of studies described their antifungal activities on pathogens affecting crops. These activities were mainly targeted to fungi and oomycetes including Botrytis sp., Rhizoctonia sp., Fusarium sp., Alternaria sp., Pythium sp., Phytophthora sp., or Plasmopara sp. species (Table 1). In these different studies, rhamnolipids, mainly originating from $P$. aeruginosa, were applied either as a mixture or purified molecules. Among all the congeners that are present in the mixtures, purified mono-rhamnolipids (Rha- $\mathrm{C}_{10}-\mathrm{C}_{10}$ ) and di-rhamnolipids (Rha-Rha- $\mathrm{C}_{10}-\mathrm{C}_{10}$ ) generally displayed the strongest activity. Moreover, all these studies demonstrated a canonical antimicrobial effect such as zoospore lysis, spore germination abortion and mycelial growth inhibition (Table 1). Because of their amphiphilic nature, glycolipids should be able to interact directly with plasma membranes (Otzen, 2017). It was thus proposed that the mode of action of rhamnolipids against zoospore-producing plant pathogens could be a direct lysis of zoospores via the intercalation of the glycolipids within plasma membranes which are not protected by a cell wall (Stanghellini and Miller, 1997). Rhamnolipids could also affect mycelial cells resulting in their destabilization or lysis. Rhamnolipid partition into membranes strongly depends on lipid composition (Aranda et al., 2007). It was shown that purified mono and dirhamnolipids are able to intercalate into phosphatidylcholine and phosphatidylethanolamine bilayers, notably altering their packing (Ortiz et al., 2006; Sánchez et al., 2006, 2009; Abbasi et al., 2012, 2013). These insertions thus produce structural perturbations, which might affect the function of the membranes. These compounds also alter the physicochemical properties of the bilayer and disturb the hydration status of the water/lipid interface. Depending on the lipid composition of the membrane and on their concentration, rhamnolipids are also able to permeabilize membranes (Sánchez et al., 2010) that could result in their lysis. Amphiphilic compounds such as glycolipids form aggregates in solution depending on their concentration. Above their critical micelle concentration (CMC), they will be present in both forms of aggregates and monomers. Although glycolipid biosurfactants are described to be stable over extreme conditions of $\mathrm{pH}$ and temperature (Mnif and Ghribi, 2016), these external factors could also influence rhamnolipid CMC, and therefore their aggregation into micelles (Zhong et al., 2015). The change in CMC could in turn affect their efficiency as biopesticide. Depending on their conformation, the glycolipids could potentially reach more or less easily the pathogen membrane (Aslam et al., 2009) to provoke its disruption (Table 1).

\section{Lipopeptides as Antimicrobial Agents}

Lipopeptide biosurfactants (LPs) are composed of a lipid tail linked to a short linear or cyclic oligopeptide. They are produced by fungi and various bacterial genera mainly in the cyclized form and have received considerable attention for their antimicrobial, cytotoxic, antitumor, immunosuppressant and surfactant properties (Raaijmakers et al., 2010). Cyclic lipopeptides (CLPs) represent a class of biosurfactant widely produced by various bacterial species referred as plant-beneficial bacteria (Ongena and Jacques, 2008; D'aes et al., 2010). Among them, Bacillus and Pseudomonas are exploited as biocontrol agents and are also the best known for the production of a range of structurally distinct and multifunctional CLPs with strong biological activities related to plant protection (D'aes et al., 2010; Raaijmakers et al., 2010). Bacterial CLPs are powerful biosurfactants retaining strong destabilizing activities on biological membranes. Their antimicrobial activity is well documented in a context of biocontrol via direct inhibition of phytopathogens. In vitro-based assays using purified CLPs combined or not with loss of function mutants of natural producers have highlighted the extremely wide range of fungal 
TABLE 1 | Anti-phytopathogenic properties of rhamnolipids.

\begin{tabular}{|c|c|c|c|c|}
\hline Compositions & Source organisms & Sensitive phytopathogens & Effects & References \\
\hline Rha-Rha- $\mathrm{C}_{10}-\mathrm{C}_{10}$ & Pseudomonas aeruginosa B5 & $\begin{array}{l}\text { Cercospora kikuchii, } \\
\text { Cladosporium cucumerinum, } \\
\text { Colletotrichum orbiculare, } \\
\text { Cylindrocarpon destructans, } \\
\text { Magnaporthe grisea, } \\
\text { Phytophthora capsici }\end{array}$ & $\begin{array}{l}\text { Zoospore lysis, spore } \\
\text { germination and hyphal growth } \\
\text { inhibition }\end{array}$ & Kim et al., 2000 \\
\hline $\begin{array}{l}\text { Rha-Rha- } \mathrm{C}_{10}-\mathrm{C}_{10} \\
\text { Rha- } \mathrm{C}_{10}-\mathrm{C}_{10} \\
\text { Rha-Rha- } \\
\text { Rha- } \mathrm{C}_{10}-\mathrm{C}_{12} \text {, } \\
\text { Rhe } \\
\text { Rha- } \mathrm{C}_{12: 2}, \text { Rha- } \mathrm{C}_{12: 1}-\mathrm{C}_{10} \text {, } \\
\text { Rha: } \mathrm{C}_{8: 2}\end{array}$ & $\begin{array}{l}\text { Pseudomonas aeruginosa } \\
\text { AT10 }\end{array}$ & $\begin{array}{l}\text { Botrytis cinerea, Rhizoctonia } \\
\text { solani, Colletotrichum } \\
\text { gloeosporioides, Fusarium } \\
\text { solani, Penicillium funiculosum }\end{array}$ & Growth inhibition (MIC) & Abalos et al., 2001 \\
\hline $\begin{array}{l}\text { Rha-Rha- } C_{10}-C_{10} \\
\text { Rha- } C_{10}-C_{10} \\
\text { Rha-Rha- } \\
\text { Rha- } C_{10}-C_{12: 1} \text {, } \\
\text { Rh: } \\
\text { Rha-Rha- } C_{10}-C_{12} \\
\text { Rha- } C_{10}-C_{12}\end{array}$ & Pseudomonas aeruginosa LBI & $\begin{array}{l}\text { Penicillium funiculosum, } \\
\text { Alternaria alternata }\end{array}$ & Growth inhibition (MIC) & Benincasa et al., 2004 \\
\hline $\begin{array}{l}\text { Rha-Rha- } \mathrm{C}_{10}-\mathrm{C}_{10} \text {, } \\
\text { Rha- } \mathrm{C}_{10}-\mathrm{C}_{10} \text { (Jeneil } \\
\text { Biosurfactant Company } \\
\text { JBR599) Biosurfactant PRO1 } \\
\text { (formulation of } 25 \% \text { RLs) Plant } \\
\text { support (the Netherlands) }\end{array}$ & Pseudomonas aeruginosa & Pythium myriotylum & Mycelial growth inhibition & Perneel et al., 2008 \\
\hline $\begin{array}{l}\text { Rha-Rha- } \mathrm{C}_{10}-\mathrm{C}_{10} \\
\text { Rha- } \mathrm{C}_{10}-\mathrm{C}_{10} \text { (Jeneil } \\
\text { Biosurfactant Company } \\
\text { JBR599) }\end{array}$ & Pseudomonas aeruginosa & Botrytis cinerea & $\begin{array}{l}\text { Spore germination and mycelial } \\
\text { growth inhibition }\end{array}$ & $\begin{array}{l}\text { Varnier et al., 2009; } \\
\text { Monnier et al., } 2018\end{array}$ \\
\hline $\begin{array}{l}\text { Rha-Rha- } \mathrm{C}_{10}-\mathrm{C}_{10} \\
\text { Rha- } \mathrm{C}_{10}-\mathrm{C}_{10}\end{array}$ & $\begin{array}{l}\text { Pseudomonas aeruginosa } \\
\text { ZJU211 }\end{array}$ & $\begin{array}{l}\text { Phytophthora infestans, } \\
\text { Phytophthora capsici, Botrytis } \\
\text { cinerea, Fusarium } \\
\text { graminearum, Fusarium } \\
\text { oxysporum }\end{array}$ & Mycelial growth Inhibition & Sha et al., 2012 \\
\hline $\begin{array}{l}\text { Rha- } C_{8: 1}, \text { Rha- } C_{10}-C_{10: 1}, \\
\text { Rha- } C_{10: 1}-C_{10}, \\
\text { Rha-Rha- } C_{10}-C_{12: 1}, \\
\text { Rha-Rha- } C_{12: 1}-C_{10}\end{array}$ & Pseudomonas aeruginosa DS9 & Fusarium sacchari & Mycelial growth Inhibition & Goswami et al., 2014 \\
\hline
\end{tabular}


TABLE 1 | Continued

\begin{tabular}{|c|c|c|c|c|}
\hline Compositions & Source organisms & Sensitive phytopathogens & Effects & References \\
\hline Mono- and di-rhamnolipids & $\begin{array}{l}\text { Pseudomonas aeruginosa } \\
\text { ZJU-211 }\end{array}$ & Alternaria alternata & $\begin{array}{l}\text { Spore germination and mycelial } \\
\text { growth inhibition }\end{array}$ & $\begin{array}{l}\text { Yan et al., 2014; Yan } \\
\text { et al., } 2015\end{array}$ \\
\hline $\begin{array}{l}\text { Rha- } C_{10}-C_{10}, \\
\text { Rha-Rha- } C_{10}-C_{8} \text {, Other Rha or } \\
\text { Rha-Rha: }-C_{10}-C_{10},-C_{8}-C_{10} \text {, } \\
-C_{10}-C_{12},-C_{12}-C_{12},-C_{14}-C_{10} \text {, } \\
-C_{10}-C_{16}\end{array}$ & Serratia rubidaea SNAU02 & $\begin{array}{l}\text { Fusarium oxysporum, } \\
\text { Colletotrichum gloeosporioides }\end{array}$ & Mycelial growth Inhibition & $\begin{array}{l}\text { Nalini and } \\
\text { Parthasarathi, } 2014\end{array}$ \\
\hline $\begin{array}{l}\text { Various mixtures of mono- } \\
\text { (Rha) or di-rhamnolipids } \\
\text { (Rha-Rha): }-\mathrm{C}_{10}-\mathrm{C}_{8} /-\mathrm{C}_{8}-\mathrm{C}_{10} \\
-\mathrm{C}_{10}-\mathrm{C}_{10: 1} /-\mathrm{C}_{10: 1}-\mathrm{C}_{10} \\
-\mathrm{C}_{10}-\mathrm{C}_{10},-\mathrm{C}_{10}-\mathrm{C}_{12: 1} /-\mathrm{C}_{12: 1}- \\
\mathrm{C}_{10} /-\mathrm{C}_{10: 1}-\mathrm{C}_{12} /-\mathrm{C}_{12}-\mathrm{C}_{10: 1} \\
-\mathrm{C}_{10}-\mathrm{C}_{12} /-\mathrm{C}_{12}-\mathrm{C}_{10}\end{array}$ & Pseudomonas aeruginosa & Phytophthora sojae & Zoospore motility inhibition & Miao et al., 2015 \\
\hline $\begin{array}{l}\text { Rha-Rha- } \mathrm{C}_{8}-\mathrm{C}_{10} \text {, Rha- } \mathrm{C}_{8}-\mathrm{C}_{10} \text {, } \\
\text { Rha-Rha- } \mathrm{C}_{10}-\mathrm{C}_{10} \text {, } \\
\text { Rha- } \mathrm{C}_{10}-\mathrm{C}_{10} \\
\text { Rha- } R \text { ha- }-\mathrm{C}_{10}-\mathrm{C}_{12} \text {, } \\
\text { Rha- } \mathrm{C}_{10}-\mathrm{C}_{12} \text { and purified } \\
\text { Rha- }-\mathrm{Rha}_{10}-\mathrm{C}_{10} \text { or } \\
\text { Rha- } \mathrm{C}_{10}-\mathrm{C}_{10}\end{array}$ & Pseudomonas aeruginosa & Phytophthora sojae & $\begin{array}{l}\text { Zoospore motility and mycelial } \\
\text { growth inhibition }\end{array}$ & $\begin{array}{l}\text { Dashtbozorg et al., } \\
2016\end{array}$ \\
\hline $\begin{array}{l}\text { Rha- } C_{9: 2}, \text { Rha- } C_{10}, \text { Rha- } C_{12: 3} \text {, } \\
\text { Rha- } C_{8}-C_{8}, \text { Rha- } C_{10}-C_{10: 1} \\
\text { Rha- } C_{10: 1}-C_{10}, \text { Rha- } C_{10}-C_{8} \text {, } \\
\text { Rha- } C_{8}-C_{10} \\
\text { Rha-Rha- } C_{10}-C_{12} \\
\text { Rha-Rha- } C_{12}-C_{10}\end{array}$ & $\begin{array}{l}\text { Pseudomonas aeruginosa } \\
\text { SS14 }\end{array}$ & Fusarium oxysporum f. sp. pisi & Fungal growth inhibition & Borah et al., 2015 \\
\hline $\begin{array}{l}\text { Rha- } \mathrm{C}_{10}-\mathrm{C}_{10} \\
\text { Rha-Rha- } \mathrm{C}_{10}-\mathrm{C}_{10}\end{array}$ & $\begin{array}{l}\text { Pseudomonas aeruginosa } \\
\text { KVD-HM52 }\end{array}$ & Fusarium oxysporum & $\begin{array}{l}\text { Mycelial growth and fungal } \\
\text { biomass accumulation inhibition }\end{array}$ & Deepika et al., 2015 \\
\hline $\begin{array}{l}\text { Rha- } C_{8: 2}, \text { Rha- } C_{8: 1} \text {, Rha- } C_{10} \text {, } \\
\text { Rha- } C_{12: 1} \text {, Rha-Rha- } C_{10: 1} \text {, } \\
\text { Rha- } C_{10}-C_{10: 1} / \text { Rha- } C_{10: 1}-C_{10}\end{array}$ & Pseudomonas aeruginosa DS9 & Colletotrichum falcatum & $\begin{array}{l}\text { Spore germination and mycelial } \\
\text { growth inhibition }\end{array}$ & Goswami et al., 2015 \\
\hline Rha- $\mathrm{C}_{8}$, Rha- $\mathrm{C}_{10}-\mathrm{C}_{10}$ & $\begin{array}{l}\text { Pseudomonas aeruginosa } \\
\text { SS14 }\end{array}$ & Fusarium verticillioides & $\begin{array}{l}\text { Spore germination and mycelial } \\
\text { growth inhibition }\end{array}$ & Borah et al., 2016 \\
\hline $\begin{array}{l}\text { Rha-Rha- } C_{10} \\
\text { Rha-Rha- } C_{8}-C_{10} \\
\text { Rha-Rha- } C_{10}-C_{10}\end{array}$ & Pseudomonas aeruginosa DR1 & $\begin{array}{l}\text { Sclerotium rolfsii, Fusarium } \\
\text { oxysporium, Phytophthora } \\
\text { nicotianae, Macrophomina } \\
\text { phaseolina }\end{array}$ & Mycelial growth inhibition & $\begin{array}{l}\text { Sathi Reddy et al., } \\
2016\end{array}$ \\
\hline $\begin{array}{l}\text { Rha-Rha- } \mathrm{C}_{10}-\mathrm{C}_{10} \\
\text { Rha- } \mathrm{C}_{10}-\mathrm{C}_{10}\end{array}$ & $\begin{array}{l}\text { Pseudomonas aeruginosa } \\
\text { ZJU211 }\end{array}$ & Verticillium dahliae & $\begin{array}{l}\text { Spore germination and mycelial } \\
\text { growth inhibition }\end{array}$ & Sha and Meng, 2016 \\
\hline $\begin{array}{l}\text { Rha- } C_{10}-C_{8}, \text { Rha- } C_{10}-C_{10} \\
\text { Rha- } C_{10}-C_{12: 1}, \text { Rha- } C_{10}-C_{12} \text {, } \\
\text { Rha-Rha- } C_{8}-C_{10} \\
\text { Rha-Rha- } C_{10}-C_{10} \\
\text { Rha-Rha- } C_{10}-C_{12: 1} \\
\text { Rha-Rha- } C_{10}-C_{12}\end{array}$ & $\begin{array}{l}\text { Pseudomonas aeruginosa } \\
\# 112\end{array}$ & Aspergillus carbonarius & Mycelial growth inhibition & Rodrigues et al., 2017 \\
\hline $\begin{array}{l}\text { Semipurified rhamnolipid } \\
\text { mixture (RL90-A, AGAE } \\
\text { Technologies, Corvalis, } \\
\text { United States) and RL90-N, } \\
\text { NatSurFact, Fairfax, } \\
\text { United States) }\end{array}$ & Pseudomonas aeruginosa & Leptosphaeria maculans & Mycelial growth inhibition & Monnier et al., 2020 \\
\hline
\end{tabular}

and oomycete plant pathogens that are affected by bacterial CLPs such as fengycins and iturins (see recent reviews (Caulier et al., 2019; Rabbee et al., 2019) for Bacillus and (Geudens and Martins, 2018; Götze and Stallforth, 2020) for Pseudomonas CLPs, respectively). Many studies indicate that CLP activity is linked to their capacity to compromise the fungal cell membrane stability, resulting in cytoplasm leakage and hyphae death or inhibition of spore germination (Chitarra et al., 2003; Romero et al., 2007; Etchegaray et al., 2008; Pérez-García et al., 2011; Gong et al., 2015; Qian et al., 2016). However, the mechanistic basis of antifungal activity may be more complex and, as for rhamnolipids, the lipid composition of the targeted cell membrane could play an essential role in the microbicidal activity (Grau et al., 1999; Tao et al., 2011; Wise et al., 2014). 
Like other antimicrobial peptides, CLPs are not only membrane disruptive but can also directly or indirectly act on intracellular targets and alter fungal cell functions (Latoud et al., 1987; Qi et al., 2010).

Antibacterial activity has also been occasionally reported for Bacillus CLPs such as iturin A, bacillomycin and locillomycins toward several plant pathogens of agronomic importance (Zeriouh et al., 2011; Luo et al., 2015; Cao et al., 2018). However, there are globally few convincing evidences for a direct bactericidal effect of Bacillus CLPs and surfactin in particular on phytopathogens or soil-borne bacterial attackers. The precise antibiotic mechanistic of Bacillus CLPs against bacterial phytopathogens remains unclear even if a direct interaction with the cellular membrane of the target is also obvious (Zeriouh et al., 2011; Gao et al., 2017). However, in some instances, the inhibitory effect of some Bacillus CLPs such as surfactin (or related lichenysin and pumilacidin) is not related to a direct effect on target cell viability but rather due to some interference with key developmental processes of the pathogen such as efficient biofilm formation by Pseudomonas syringae and Ralstonia solanacearum (Bais et al., 2004; Chen et al., 2013; Xiu et al., 2017) or inhibition of aerial hyphal development of Streptomyces coelicolor (Straight et al., 2006; Hoefler et al., 2012).

\section{STIMULATION OF PLANT IMMUNITY BY BIOSURFACTANTS}

Plants have developed complex defense mechanisms leading to enhance resistance to phytopathogens. After microbial perception, early signaling events are set up including ion fluxes, reactive oxygen species (ROS) accumulation and phosphorylation cascades (Garcia-Brugger et al., 2006; Bigeard et al., 2015). These early signaling and the activation of an intricate network of phytohormones, such as salicylic acid or jasmonic acid, regulate late defense-related responses (Pieterse et al., 2012) including synthesis of antimicrobial metabolites and cell wall reinforcement. These defense responses collectively allow local plant immunity (Boller and Felix, 2009). In addition, microbial perception triggers systemic responses that are effective against a large panel of microorganisms in the whole plant (Fu and Dong, 2013; Pieterse et al., 2014). Activation of the plant immune system involves invasion patterns (IPs) molecules also known as elicitors which can originate from or be produced by the microbe (Schellenberger et al., 2019).

\section{Rhamnolipids Trigger Local Resistance Against Plant Pathogens}

Whereas most studies on glycolipid biosurfactants were focused on their antimicrobial and antifouling activities, it was recently discovered that rhamnolipids may also stimulate plant innate immunity (Vatsa et al., 2010; Figure 1). Interestingly, despite their antimicrobial and mammalian immunomodulatory properties, to our knowledge, no study on sophorolipids, trehalolipids, MELs or cellobiose lipids, described their potential role in the activation of plant defense responses so far. Following plant sensing, rhamnolipids trigger early signaling events like accumulation of ROS in grapevine and Brassica napus (Varnier et al., 2009; Monnier et al., 2018) as well as a calcium influx and a phosphorylation cascade in grapevine (Varnier et al., 2009). Callose deposition, hormone production, defense gene activation and a hypersensitive reaction-like response are also hallmarks of rhamnolipid-triggered immunity in Brassicaceae and grapevine (Varnier et al., 2009; Sanchez et al., 2012; Monnier et al., 2018, 2020). It was demonstrated in Arabidopsis that rhamnolipid-mediated local resistance to Botrytis cinerea, Hyaloperonospora arabidopsidis or $P$. syringae pv. tomato (Pst) involves different signaling pathways that depend on the type of pathogen (Sanchez et al., 2012). In addition, rhamnolipid potentiate defense responses induced by other elicitors like chitosan. The immune response triggered by rhamnolipids also participates in local resistance against $B$. cinerea and the hemibiotrophic fungus Leptosphaeria maculans in $B$. napus (Monnier et al., 2018, 2020). A large range of rhamnolipid concentrations from 0.005 to $1 \mathrm{mg} / \mathrm{mL}$ have been used to induce immunity on these various plant species (Varnier et al., 2009; Sanchez et al., 2012; Monnier et al., 2018, 2020). Synthetic biosurfactants derived from rhamnolipid structure are also elicitors. For instance, synthetic rhamnolipid bolaforms, composed of two rhamnoses separated by a fatty acid chain, trigger an immune response in Arabidopsis that varies according to fatty acid chain length (Luzuriaga-Loaiza et al., 2018). In addition, RL harboring carboxylic acid (Ac$\mathrm{RL}$ ) and methyl (Alk-RL) induce ROS production in this plant (Nasir et al., 2017).

The way by which rhamnolipids are perceived by plant cells still remains unknown. Given their amphiphilic nature, it is postulated that they could interact with plant membrane lipids (Sanchez et al., 2012; Schellenberger et al., 2019). Recently it has been demonstrated that natural rhamnolipids fit into plant lipidbased membrane models and are located near the lipid phosphate group of the phospholipid bilayers, nearby phospholipid glycerol backbones (Monnier et al., 2019). Rhamnolipid insertion inside the lipid bilayer does not strongly affect lipid dynamics but the nature of the phytosterols could influence the effect of the glycolipids on plant plasma membrane destabilization. These subtle changes in lipid dynamics could be linked with plant defense induction (Monnier et al., 2019). Interestingly, whereas no receptor for rhamnolipid perception has been identified so far, the mc-3-OH-acyl building block of rhamnolipids is sensed by the lectin S-domain-1 receptor-like kinase LORE (Kutschera et al., 2019; Figure 1).

For some studies, it is not demonstrated whether rhamnolipidtriggered protection is driven by activation of plant defense responses and/or antimicrobial properties. For instance, treatments of pepper plants with rhamnolipids result in an enhanced protection to Phytophthora blight disease and also prevent the development of Colletotrichum orbiculare infection on leaves of cucumber plants (Kim et al., 2000). Rhamnolipids significantly decrease the incidence of water-borne damping-off disease by Phytophthora sp. and Pythium sp. (Yoo et al., 2005). Similar results were obtained in field trials on chili pepper and tomato (Sharma et al., 2007a,b). Using bacterial mutants, it was 


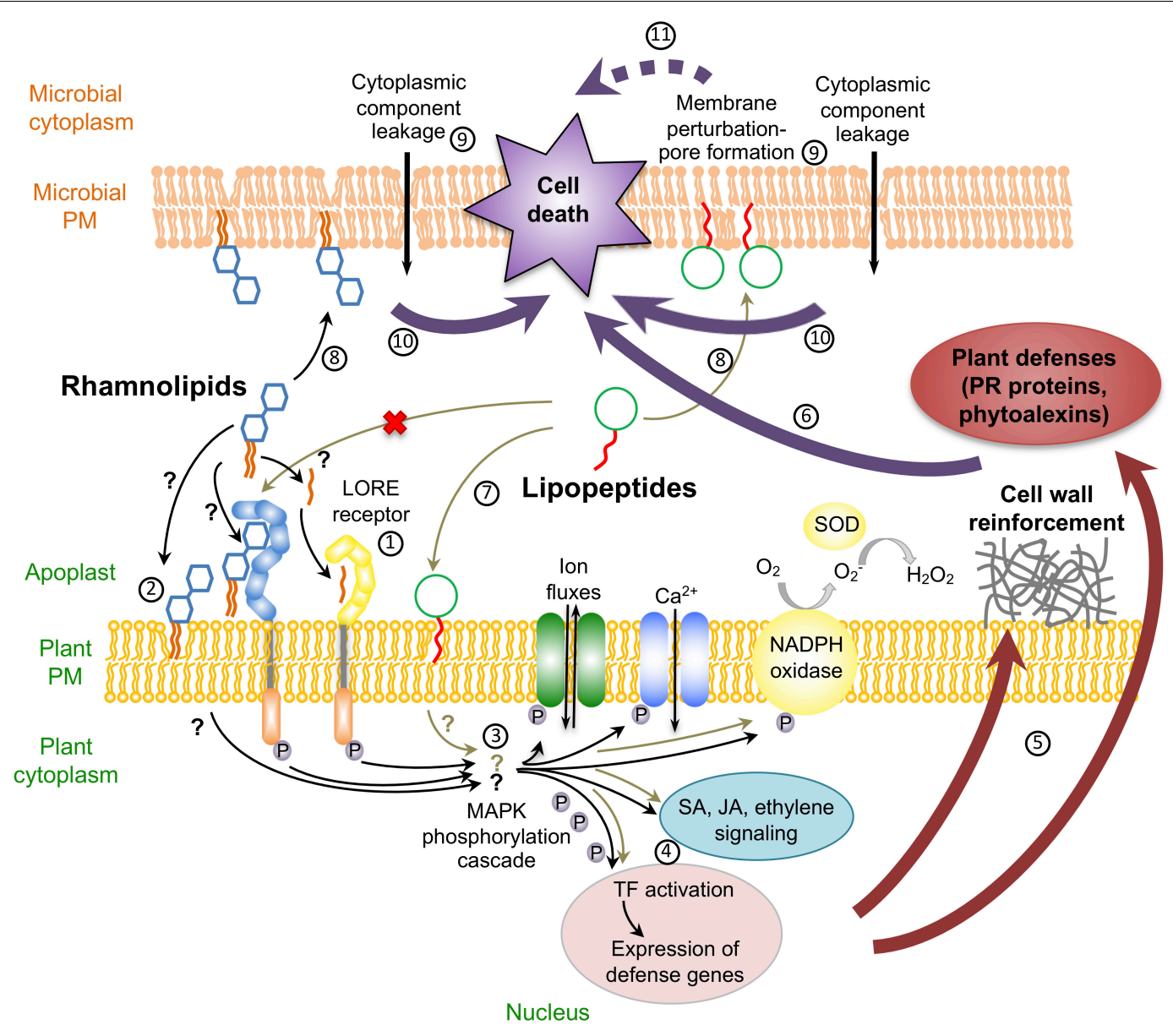

FIGURE 1 | Schematic representation of dual effects of rhamnolipids and lipopeptides: antimicrobial activities and plant defense induction. mc-3-OH-acyl building block of rhamnolipids is perceived by plant through the LORE receptor (1); Rhamnolipid could be sensed through their direct insertion in plasma membrane (2). Recognition of rhamnolipids leads to early signaling events like ion fluxes $\left(\mathrm{Ca}^{2+}\right)$, reactive oxygen species production $\left(\mathrm{H}_{2} \mathrm{O}_{2}\right)$ and $\mathrm{MAPK}$ phosphorylation cascade (3). These early responses trigger defense gene expression, probably through activation of transcription factors (TF) and hormonal signaling pathways (4). This leads to defense mechanisms like cell wall reinforcement and PR protein accumulation (5) triggering the resistance to the microbes (6). Plant immunity due to lipopeptides does not involve a protein receptor and rely on interaction between lipopeptides and the plant membrane (7). Both rhamnolipids and lipopeptides can also have direct antimicrobial effects through direct insertion into the microbial plasma membrane (8). These insertions trigger loss of cell morphology leading to pore formation (9). The pore formation causes cellular component leakage triggering microbial cell death (10. Cell death due to lipopeptides can also be indirectly due to the inhibition or activation of microbial cell functions (11).

demonstrated that phenazine and rhamnolipids interact in the biological control of soil-borne diseases caused by Pythium sp. (Perneel et al., 2008). Syringomycin E and rhamnolipids can also act synergistically to control pathogenic and opportunistic fungi recovered from diseased grape (Takemoto et al., 2010). The control of postharvest phytopathogens on seeds or fruits for a better conservation is often related to antimicrobial activities. But we cannot exclude that protection could also be due to plant defense responses (Borah et al., 2016). When applied alone, rhamnolipids induce antioxidative reactions in cherry tomato fruit, leading to a significant reduction of fungal disease (Yan et al., 2015). When applied in combination with the biocontrol yeast agent Rhodotorula glutinis, a synergistic inhibitory effect on Alternaria alternata infection could be observed in cherry tomato fruit, leading to an efficient protection (Yan et al., 2014). This protection is associated with a higher induction of defense-related enzymes and the accumulation of antimicrobial metabolites.

\section{Lipopeptides as Powerful Inducers of Plant Systemic Resistance}

Several studies have reported the involvement of Bacillus CLPs in plant immunity induction on various pathosystems. The potential of fengycin and surfactin CLPs to trigger plant systemic resistance was first shown on bean and tomato plants. When applied as pure compounds at micromolar concentrations, surfactin and to a lower extend fengycin induced significant disease reduction in bean and tomato infected with $B$. cinerea (Ongena et al., 2007). More recently, a study performed with a large range of natural Bacillus isolates strengthened the role of surfactin as ISR (induced systemic resistance) inducer 
since strong correlation was observed between defense-inducing activity and the amount of surfactin produced by the different strains (Cawoy et al., 2014). In the same way, B. velezensis FZB42 mutant strains unable to synthesize surfactin are impaired in their ISR to Rhizoctonia solani in lettuce (Chowdhury et al., 2015). Further studies allowed enlarging the ISR elicitor role of surfactin to other plants. For example, purified surfactin was shown to increase resistance against the cucurbit powdery mildew in melon plants (García-Gutiérrez et al., 2013). In the pathosystem citrus fruit/Penicillium digitatum, surfactin stimulates defense responses involved in generating signal molecules for ISR activation (Waewthongrak et al., 2014). This lipopeptide activates a plant innate response effective against Magnaporthe oryzae in perennial ryegrass (Rahman et al., 2015) or Plasmopara viticola in grapevine ( $\mathrm{Li}$ et al., 2019). It also reduces infection by the rhizomania disease vector Polymyxa betae in sugar beet (Desoignies et al., 2013) or by Colletotrichum gloeosporioides in strawberry leaves (Yamamoto et al., 2015). Finally, a recent study showed that Sclerotium rolfsii disease incidence was strongly reduced in Arachis hypogaea when pretreated with surfactin (Rodríguez et al., 2018). Interestingly, CLPs like surfactin do not globally provoke a strong plant defensive response associated with major genetic reprogramming and fitness cost but rather act by priming host defenses to trigger systemic resistance (Ongena et al., 2007; Jourdan et al., 2009; Debois et al., 2015). Induction of plant defenses by CLPs of the iturin group has also been occasionally reported. Iturin A was shown to have a similar role as surfactin in strawberry leaves (Yamamoto et al., 2015) and also acted as an inducer of plant defense gene expression in cotton plants upon Verticillium dahliae attack (Han et al., 2015). Mycosubtilin is the most efficient lipopeptide inducing an immune response in grapevine (Farace et al., 2015). Compared to surfactin, bacillomycin D produced by $B$. velezensis SQR9 has a comparable efficacy in Arabidopsis ISR elicitation to prevent infection by $P$. syringae or $B$. cinerea (Wu et al., 2018). In wheat plants, resistance toward Zymoseptoria tritici, was activated by pure surfactin used at concentrations ranging from 1 to $100 \mu \mathrm{M}$ upon foliar application (Le Mire et al., 2018). Some CLPs synthesized by Pseudomonas sp. also display consistent ISR-triggering activity. It was first demonstrated that massetolide A produced by Pseudomonas fluorescens strain SS101 retains ISR-eliciting activity in tomato plants for the control of Phytophthora infestans (Tran et al., 2007). Pseudomonas sp. strain CMR12a is a soil isolate retaining high biocontrol potential against $R$. solani relying mainly on the interplay between two different lipopeptides (sessilin and orfamide) and phenazine for inducing plant immunity (D'aes et al., 2011, 2014). These CLPs were also active at protecting Brassica chinensis against $R$. solani (Olorunleke et al., 2015). In monocots, such as rice, orfamide and other Pseudomonas CLPs such as WLIP, lokisin and entolysin, successfully induced resistance toward C. miyabeanus or M. oryzae (Ma et al., 2016, 2017; Omoboye et al., 2019).

Up to now, how lipopeptides act and are recognized by plant cells to activate ISR remains unclear. CLPs are in most instances only active in micromolar concentrations, and defenses are more intensively induced at the highest surfactin doses. This suggests that the recognition mechanism at the plant cell surface should be of quite low affinity in contrast to other elicitors (Jourdan et al., 2009). Such a low specificity may be explained by the fact that CLPs like surfactin are not perceived by a protein receptor, but rather involve a process driven by an uncommon pathway based on interaction with the lipid bilayer fraction of plant plasma membranes (Henry et al., 2011). This is supported by some studies revealing that CLP structure plays an important role for the ISR eliciting activity. Both the fatty acid chain length, the cyclic conformation of the molecule and amino acid positions in the peptide chain impact the eliciting potential of surfactin in tobacco cells (Jourdan et al., 2009; Henry et al., 2011). The activation of defense genes in Arabidopsis upon iturin A foliar treatment was also dependent on the structure of the molecule, i.e., cyclization and/or nature of the fatty acid chain (Kawagoe et al., 2015). As for rhamnolipids, the hypothesis is that lipopeptides have the ability to create some disturbance in the plant plasma membrane and could consequently activate a cascade of molecular events leading to the activation of defense mechanisms (Schellenberger et al., 2019; Figure 1).

\section{CONCLUSION}

Biosurfactants, produced by bacteria, yeast, and fungi, are promising molecules for a wide variety of applications due to their potential to be commercially produced at large scales, their low toxicity and high biodegradability. In this mini-review, we provided evidences about the potential of rhamnolipids and lipopeptides for plant protection in a context of sustained agriculture. These molecules have similar dual effects by protecting plants through antimicrobial properties and stimulation of local and/or systemic plant immunity. These singular properties are essential for the efficiency of these biopesticides. Although numerous elicitors are perceived by plasma membrane receptors, recent studies on amphiphilic biosurfactants such as rhamnolipids or lipopeptides suggest that they are sensed by an uncommon way involving lipids in the bilayer of the plant plasma membrane that could explain their singular elicitor activity. To better understand the mechanisms of action of biosurfactants, experiments or trials need to be realized not only on mixture but also on highly purified molecules in the future. Nevertheless, several obstacles to the development of rhamnolipid and lipopeptide applications still remain. Biosurfactant costs, their efficacies in the field and purity of compounds have to be improved to allow their use at a higher degree in crop protection. In this respect, combination of biosurfactants should be considered to increase efficacy in field conditions. Finally, given their interesting properties it is now time to really consider ecofriendly biosurfactants as biocontrol solutions in integrated pest management.

\section{AUTHOR CONTRIBUTIONS}

JC, AA-A, SD-C, SC, MO, and SD participated in the conception, information search, and assisted in drafting the manuscript. JP, 
GH, FM-G, FB, and CC assisted in drafting and correction of the manuscript. All authors contributed to the article and approved the submitted version.

\section{FUNDING}

Research in the MO lab is funded by the EOS (excellence of science, FRS-FNRS) grant no. 2018000802.

\section{REFERENCES}

Abalos, A., Pinazo, A., Infante, M. R., Casals, M., García, F., and Manresa, A. (2001). Physicochemical and antimicrobial properties of new rhamnolipids produced by Pseudomonas aeruginosa AT10 from soybean oil refinery wastes. Langmuir 17, 1367-1371. doi: 10.1021/la0011735

Abbasi, H., Aranda, F. J., Noghabi, K. A., and Ortiz, A. (2013). A bacterial monorhamnolipid alters the biophysical properties of phosphatidylethanolamine model membranes. Biochim. Biophys. Acta Biomemb. 1828, 2083-2090. doi: 10.1016/j.bbamem.2013.04.024

Abbasi, H., Noghabi, K. A., and Ortiz, A. (2012). Interaction of a bacterial monorhamnolipid secreted by Pseudomonas aeruginosa MA01 with phosphatidylcholine model membranes. Chem. Phys. Lipids 165, 745-752. doi: 10.1016/j.chemphyslip.2012.09.001

Abdel-Mawgoud, A. M., Lepine, F., and Deziel, E. (2010). Rhamnolipids: diversity of structures, microbial origins and roles. Appl. Microbiol. Biotechnol. 86, 1323-1336. doi: 10.1007/s00253-010-2498-2

Aranda, F. J., Espuny, M. J., Marqués, A., Teruel, J. A., Manresa, Á, and Ortiz, A. (2007). Thermodynamics of the interaction of a dirhamnolipid biosurfactant secreted by Pseudomonas aeruginosa with phospholipid membranes. Langmuir 23, 2700-2705. doi: 10.1021/la061464z

Aslam, S. N., Erbs, G., Morrissey, K. L., Newman, M.-A., Chinchilla, D., Boller, T., et al. (2009). Microbe-associated molecular pattern (MAMP) signatures, synergy, size and charge: influences on perception or mobility and host defence responses. Mol. Plant Pathol. 10, 375-387. doi: 10.1111/j.1364-3703.2009. 00537.x

Bais, H. P., Fall, R., and Vivanco, J. M. (2004). Biocontrol of Bacillus subtilis against infection of Arabidopsis roots by Pseudomonas syringae is facilitated by biofilm formation and surfactin production. Plant Physiol. 134, 307-319. doi: $10.1104 /$ pp.103.028712

Banat, I. M., Franzetti, A., Gandolfi, I., Bestetti, G., Martinotti, M. G., Fracchia, L., et al. (2010). Microbial biosurfactants production, applications and future potential. Appl. Microbiol. Biotechnol. 87, 427-444. doi: 10.1007/s00253-0102589-0

Bardin, M., Ajouz, S., Comby, M., Lopez-Ferber, M., Graillot, B., Siegwart, M., et al. (2015). Is the efficacy of biological control against plant diseases likely to be more durable than that of chemical pesticides? Front. Plant Sci. 6:566. doi: $10.3389 /$ fpls.2015.00566

Benincasa, M., Abalos, A., Oliveira, I., and Manresa, A. (2004). Chemical structure, surface properties and biological activities of the biosurfactant produced by Pseudomonas aeruginosa LBI from soapstock. Antonie Van Leeuwenhoek 85, 1-8. doi: 10.1023/B:ANTO.0000020148.45523.415105181

Berg, G., Koberl, M., Rybakova, D., Muller, H., Grosch, R., and Smalla, K. (2017). Plant microbial diversity is suggested as the key to future biocontrol and health trends. FEMS Microbiol. Ecol. 93:fix050. doi: 10.1093/femsec/ fix 050

Bigeard, J., Colcombet, J., and Hirt, H. (2015). Signaling mechanisms in patterntriggered immunity (PTI). Mol. Plant 8, 521-539. doi: 10.1016/j.molp.2014.12. 022

Boller, T., and Felix, G. (2009). A renaissance of elicitors: perception of microbeassociated molecular patterns and danger signals by pattern-recognition receptors. Annu. Rev. Plant Biol. 60, 379-406. doi: 10.1146/annurev.arplant.57. 032905.105346

Bonanomi, G., Lorito, M., Vinale, F., and Woo, S. L. (2018). Organic amendments, beneficial microbes, and soil microbiota: toward a unified framework for disease

\section{ACKNOWLEDGMENTS}

Support from the MESRI (ministère de l'Enseignement supérieur, de la Recherche et de l'Innovation), the Federative Research Structure SFR Condorcet and the Interreg V France-WallonieVlaanderen program Smartbiocontrol/Bioscreen are gratefully acknowledged. MO thanks the Fonds National de la Recherche Scientifique from Belgium (FRS-FNRS) for his position as Senior Research Associate.

suppression. Annu. Rev. Phytopathol. 56, 1-20. doi: 10.1146/annurev-phyto080615-100046

Borah, S. N., Goswami, D., Lahkar, J., Sarma, H. K., Khan, M. R., and Deka, S. (2015). Rhamnolipid produced by Pseudomonas aeruginosa SS14 causes complete suppression of wilt by Fusarium oxysporum f. sp. pisi in Pisum sativum. Biocontrol 60, 375-385. doi: 10.1007/s10526-014-9645-0

Borah, S. N., Goswami, D., Sarma, H. K., Cameotra, S. S., and Deka, S. (2016). Rhamnolipid biosurfactant against Fusarium verticillioides to control stalk and ear rot disease of maize. Front. Microbiol. 7:1505. doi: 10.3389/fmicb.2016. 01505

Burketova, L., Trda, L., Ott, P. G., and Valentova, O. (2015). Bio-based resistance inducers for sustainable plant protection against pathogens. Biotechnol. Adv. 33(6 Pt 2), 994-1004. doi: 10.1016/j.biotechadv.2015.01.004

Cao, Y., Pi, H., Chandrangsu, P., Li, Y., Wang, Y., Zhou, H., et al. (2018). Antagonism of two plant-growth promoting Bacillus velezensis isolates against Ralstonia solanacearum and Fusarium oxysporum. Sci. Rep. 8:4360. doi: 10. 1038/s41598-018-22782-z

Caulier, S., Nannan, C., Gillis, A., Licciardi, F., Bragard, C., and Mahillon, J. (2019). Overview of the antimicrobial compounds produced by members of the Bacillus subtilis group. Front. Microbiol. 10:302. doi: 10.3389/fmicb.2019.00302

Cawoy, H., Mariutto, M., Henry, G., Fisher, C., Vasilyeva, N., Thonart, P., et al. (2014). Plant defense stimulation by natural isolates of Bacillus depends on efficient surfactin production. Mol. Plant Microb. Interact. 27, 87-100. doi: 10.1094/mpmi-09-13-0262-r

Chen, J., Liu, X., Fu, S., An, Z., Feng, Y., Wang, R., et al. (2020). Effects of sophorolipids on fungal and oomycete pathogens in relation to $\mathrm{pH}$ solubility. J. Appl. Microbiol. 128, 1754-1763. doi: 10.1111/jam.14594

Chen, Y., Yan, F., Chai, Y., Liu, H., Kolter, R., Losick, R., et al. (2013). Biocontrol of tomato wilt disease by Bacillus subtilis isolates from natural environments depends on conserved genes mediating biofilm formation. Environ. Microbiol. 15, 848-864. doi: 10.1111/j.1462-2920.2012.02860.x

Chitarra, G. S., Breeuwer, P., Nout, M. J. R., Van Aelst, A. C., Rombouts, F. M., and Abee, T. (2003). An antifungal compound produced by Bacillus subtilis YM 10-20 inhibits germination of Penicillium roqueforti conidiospores. J. Appl. Microbiol. 94, 159-166. doi: 10.1046/j.1365-2672.2003.01819.x

Chowdhury, S. P., Hartmann, A., Gao, X., and Borriss, R. (2015). Biocontrol mechanism by root-associated Bacillus amyloliquefaciens FZB42 - a review. Front. Microbiol. 6:780. doi: 10.3389/fmicb.2015.00780

Coelho, A. L. S., Feuser, P. E., Carciofi, B. A. M., de Andrade, C. J., and de Oliveira, D. (2020). Mannosylerythritol lipids: antimicrobial and biomedical properties. Appl. Microbiol. Biotechnol. 104, 2297-2318. doi: 10.1007/s00253-020-10354-z

D'aes, J., De Maeyer, K., Pauwelyn, E., and Höfte, M. (2010). Biosurfactants in plant-Pseudomonas interactions and their importance to biocontrol. Environ. Microbiol. Rep. 2, 359-372. doi: 10.1111/j.1758-2229.2009.00104.x

D’aes, J., Hua, G. K., De Maeyer, K., Pannecoucque, J., Forrez, I., Ongena, M., et al. (2011). Biological control of Rhizoctonia root rot on bean by phenazineand cyclic lipopeptide-producing Pseudomonas CMR12a. Phytopathology 101, 996-1004. doi: 10.1094/phyto-11-10-0315

D’aes, J., Kieu, N. P., Léclère, V., Tokarski, C., Olorunleke, F. E., De Maeyer, K., et al. (2014). To settle or to move? The interplay between two classes of cyclic lipopeptides in the biocontrol strain Pseudomonas CMR12a. Environ. Microbiol. 16, 2282-2300. doi: 10.1111/1462-2920.12462

Dashtbozorg, S. S., Miao, S., and Ju, L.-K. (2016). Rhamnolipids as environmentally friendly biopesticide against plant pathogen Phytophthora sojae. Environ. Prog. Sustain. Energy 35, 169-173. doi: 10.1002/ep.12187 
De Jonghe, K., De Dobbelaere, I., Sarrazyn, R., and Höfte, M. (2005). Control of Phytophthora cryptogea in the hydroponic forcing of witloof chicory with the rhamnolipid-based biosurfactant formulation PRO1. Plant Pathol. 54, 219-226.

Debois, D., Fernandez, O., Franzil, L., Jourdan, E., de Brogniez, A., Willems, L., et al. (2015). Plant polysaccharides initiate underground crosstalk with bacilli by inducing synthesis of the immunogenic Lipopeptide surfactin. Environ. Microbiol. Rep. 7, 570-582. doi: 10.1111/1758-2229.12286

Deepika, K. V., Ramu Sridhar, P., and Bramhachari, P. V. (2015). Characterization and antifungal properties of rhamnolipids produced by mangrove sediment bacterium Pseudomonas aeruginosa strain KVD-HM52. Biocatalys. Agric. Biotechnol. 4, 608-615. doi: 10.1016/j.bcab.2015.09.009

Delaunois, B., Farace, G., Jeandet, P., Clement, C., Baillieul, F., Dorey, S., et al. (2014). Elicitors as alternative strategy to pesticides in grapevine? Current knowledge on their mode of action from controlled conditions to vineyard. Environ. Sci. Pollut. Res. Intern. 21, 4837-4846. doi: 10.1007/s11356-0131841-4

Desoignies, N., Schramme, F., Ongena, M., and Legrève, A. (2013). Systemic resistance induced by Bacillus lipopeptides in Beta vulgaris reduces infection by the rhizomania disease vector Polymyxa betae. Mol. Plant Pathol. 14, 416-421. doi: $10.1111 / \mathrm{mpp} .12008$

Etchegaray, A., de Castro Bueno, C., de Melo, I. S., Tsai, S. M., de Fátima Fiore, M., Silva-Stenico, M. E., et al. (2008). Effect of a highly concentrated lipopeptide extract of Bacillus subtilis on fungal and bacterial cells. Archiv. Microbiol. 190, 611-622. doi: 10.1007/s00203-008-0409-z

Farace, G., Fernandez, O., Jacquens, L., Coutte, F., Krier, F., Jacques, P., et al. (2015). Cyclic lipopeptides from Bacillus subtilis activate distinct patterns of defence responses in grapevine. Mol. Plant Pathol. 16, 177-187. doi: 10.1111/ mpp. 12170

Fu, Z. Q., and Dong, X. (2013). Systemic acquired resistance: turning local infection into global defense. Annu. Rev. Plant Biol. 64, 839-863. doi: 10.1146/annurevarplant-042811-105606

Gao, L., Han, J., Liu, H., Qu, X., Lu, Z., and Bie, X. (2017). Plipastatin and surfactin coproduction by Bacillus subtilis pB2-L and their effects on microorganisms. Antonie Van Leeuwenhoek 110, 1007-1018. doi: 10.1007/s10482-017-0874-y

Garcia-Brugger, A., Lamotte, O., Vandelle, E., Bourque, S., Lecourieux, D., Poinssot, B., et al. (2006). Early signaling events induced by elicitors of plant defenses. Mol. Plant Microb. Interact. 19, 711-724.

García-Gutiérrez, L., Zeriouh, H., Romero, D., Cubero, J., de Vicente, A., and Pérez-García, A. (2013). The antagonistic strain Bacillus subtilis UMAF6639 also confers protection to melon plants against cucurbit powdery mildew by activation of jasmonate- and salicylic acid-dependent defence responses. Microb. Biotechnol. 6, 264-274. doi: 10.1111/1751-7915.12028

Geudens, N., and Martins, J. C. (2018). Cyclic lipodepsipeptides from Pseudomonas spp. - biological swiss-army knives. Front. Microbiol. 9:1867. doi: 10.3389/fmicb. 2018.01867

Gong, A.-D., Li, H.-P., Yuan, Q.-S., Song, X.-S., Yao, W., He, W.-J., et al. (2015). Antagonistic mechanism of iturin A and plipastatin A from Bacillus amyloliquefaciens S76-3 from wheat spikes against Fusarium graminearum. PLoS One 10:e0116871. doi: 10.1371/journal.pone.0116871

Goswami, D., Borah, S. N., Lahkar, J., Handique, P. J., and Deka, S. (2015). Antifungal properties of rhamnolipid produced by Pseudomonas aeruginosa DS9 against Colletotrichum falcatum. J. Basic Microbiol. 55, 1265-1274. doi: 10.1002/jobm.201500220

Goswami, D., Handique, P. J., and Deka, S. (2014). Rhamnolipid biosurfactant against Fusarium sacchari-the causal organism of pokkah boeng disease of sugarcane. J. Basic Microbiol. 54, 548-557. doi: 10.1002/jobm.201200801

Götze, S., and Stallforth, P. (2020). Structure, properties, and biological functions of nonribosomal lipopeptides from pseudomonads. Nat. Product Rep. 37, 29-54. doi: 10.1039/c9np00022d

Grau, A., Gómez Fernández, J. C., Peypoux, F., and Ortiz, A. (1999). A study on the interactions of surfactin with phospholipid vesicles. Biochim. Biophys. Acta Biomemb. 1418, 307-319. doi: 10.1016/S0005-2736(99)00039-5

Haba, E., Pinazo, A., Jauregui, O., Espuny, M. J., Infante, M. R., and Manresa, A. (2003). Physiochemical characterization and antimicrobial properties of rhamnolipids produced by Pseudomonas aeruginosa 47T2 NCBIM 40044. Biotechnol. Bioeng. 81, 316-322.

Han, Q., Wu, F., Wang, X., Qi, H., Shi, L., Ren, A., et al. (2015). The bacterial lipopeptide iturins induce Verticillium dahliae cell death by affecting fungal signalling pathways and mediate plant defence responses involved in pathogenassociated molecular pattern-triggered immunity. Environ. Microbiol. 17, 1166 1188. doi: 10.1111/1462-2920.12538

Henry, G., Deleu, M., Jourdan, E., Thonart, P., and Ongena, M. (2011). The bacterial lipopeptide surfactin targets the lipid fraction of the plant plasma membrane to trigger immune-related defence responses. Cell. Microbiol. 13, 1824-1837. doi: 10.1111/j.1462-5822.2011.01664.x

Hoefler, B. C., Gorzelnik, K. V., Yang, J. Y., Hendricks, N., Dorrestein, P. C., and Straight, P. D. (2012). Enzymatic resistance to the lipopeptide surfactin as identified through imaging mass spectrometry of bacterial competition. Proc. Natl. Acad. Sci. U.S.A. 109, 13082-13087. doi: 10.1073/pnas.1205586109

Jahan, R., Bodratti, A. M., Tsianou, M., and Alexandridis, P. (2020). Biosurfactants, natural alternatives to synthetic surfactants: physicochemical properties and applications. Adv. Coll. Interf. Sci. 275:102061. doi: 10.1016/j.cis.2019.102061

Jourdan, E., Henry, G., Duby, F., Dommes, J., Barthelemy, J. P., Thonart, P., et al. (2009). Insights into the defense-related events occurring in plant cells following perception of surfactin-type lipopeptide from Bacillus subtilis. Mol. Plant Microb. Interact. 22, 456-468. doi: 10.1094/MPMI-22-4-0456

Kawagoe, Y., Shiraishi, S., Kondo, H., Yamamoto, S., Aoki, Y., and Suzuki, S. (2015). Cyclic lipopeptide iturin A structure-dependently induces defense response in Arabidopsis plants by activating SA and JA signaling pathways. Biochem. Biophys. Res. Commun. 460, 1015-1020. doi: 10.1016/j.bbrc.2015.03.143

Keswani, C., Singh, H. B., Hermosa, R., Garcia-Estrada, C., Caradus, J., He, Y. W., et al. (2019). Antimicrobial secondary metabolites from agriculturally important fungi as next biocontrol agents. Appl. Microbiol. Biotechnol. 103, 9287-9303. doi: 10.1007/s00253-019-10209-2

Kim, B. S., Lee, J. Y., and Hwang, B. K. (2000). In vivo control and in vitro antifungal activity of rhamnolipid B, a glycolipid antibiotic, against Phytophthora capsici and Colletotrichum orbiculare. Pest Manag. Sci. 56, 1029-1035.

Kutschera, A., Dawid, C., Gisch, N., Schmid, C., Raasch, L., Gerster, T., et al. (2019). Bacterial medium-chain 3-hydroxy fatty acid metabolites trigger immunity in Arabidopsis plants. Science 364, 178-181. doi: 10.1126/science.aau1279

Lang, S., Katsiwela, E., and Wagner, F. (1989). Antimicrobial effects of biosurfactants. Lipid Fett 91, 363-366. doi: 10.1002/lipi.19890910908

Latoud, C., Peypoux, F., and Michel, G. (1987). Action of iturin A, an antifungal antibiotic from Bacillus subtilis, on the yeast Saccharomyces cerevisiae: modifications of membrane permeability and lipid composition. J. Antibiot. 40, 1588-1595. doi: 10.7164/antibiotics.40.1588

Le Mire, G., Siah, A., Brisset, M.-N., Gaucher, M., Deleu, M., and Jijakli, M. H. (2018). Surfactin Protects Wheat against Zymoseptoria tritici and activates both salicylic acid- and jasmonic acid-dependent defense responses. Agriculture $8: 11$.

Li, Y., Héloir, M.-C., Zhang, X., Geissler, M., Trouvelot, S., Jacquens, L., et al. (2019). Surfactin and fengycin contribute to the protection of a Bacillus subtilis strain against grape downy mildew by both direct effect and defence stimulation. Mol. Plant Pathol. 20, 1037-1050. doi: 10.1111/mpp.12809

Luo, C., Zhou, H., Zou, J., Wang, X., Zhang, R., Xiang, Y., et al. (2015). Bacillomycin $\mathrm{L}$ and surfactin contribute synergistically to the phenotypic features of Bacillus subtilis 916 and the biocontrol of rice sheath blight induced by Rhizoctonia solani. Appl. Microbiol. Biotechnol. 99, 1897-1910. doi: 10.1007/s00253-0146195-4

Luzuriaga-Loaiza, P., Schellenberger, R., De Gaetano, Y., Obounou Akong, F., Villaume, S., Crouzet, J., et al. (2018). Synthetic Rhamnolipid bolaforms trigger an innate immune response in Arabidopsis thaliana. Sci. Rep. 8:8534.

Ma, Z., Hua, G. K. H., Ongena, M., and Hofte, M. (2016). Role of phenazines and cyclic lipopeptides produced by pseudomonas sp. CMR12a in induced systemic resistance on rice and bean. Environ. Microbiol. Rep. 8, 896-904. doi: 10.1111/1758-2229.12454

Ma, Z., Ongena, M., and Hofte, M. (2017). The cyclic lipopeptide orfamide induces systemic resistance in rice to Cochliobolus miyabeanus but not to Magnaporthe oryzae. Plant Cell Rep. 36, 1731-1746. doi: 10.1007/s00299-0172187-z

Miao, S., Dashtbozorg, S. S., Callow, N. V., and Ju, L.-K. (2015). Rhamnolipids as platform molecules for production of potential anti-zoospore agrochemicals. J. Agric. Food Chem. 63, 3367-3376. doi: 10.1021/acs.jafc.5b00033

Mnif, I., and Ghribi, D. (2016). Glycolipid biosurfactants: main properties and potential applications in agriculture and food industry. J. Sci. Food Agric. 96, 4310-4320. doi: 10.1002/jsfa.7759 
Monnier, N., Cordier, M., Dahi, A., Santoni, V., Guenin, S., Clement, C., et al. (2020). Semi-purified rhamnolipid mixes protect Brassica napus against Leptosphaeria maculans early infections. Phytopathology 110, 834-842. doi: 10. 1094/phyto-07-19-0275-r

Monnier, N., Furlan, A., Botcazon, C., Dahi, A., Mongelard, G., Cordelier, S., et al. (2018). Rhamnolipids from Pseudomonas aeruginosa are elicitors triggering Brassica napus protection against Botrytis cinerea without physiological disorders. Front. Plant Sci. 9:1170. doi: 10.3389/fpls.2018.01170

Monnier, N., Furlan, A. L., Buchoux, S., Deleu, M., Dauchez, M., Rippa, S., et al. (2019). Exploring the dual interaction of natural rhamnolipids with plant and fungal biomimetic plasma membranes through biophysical studies. Intern. J. Mol. Sci. 20:1009. doi: 10.3390/ijms20051009

Nalini, S., and Parthasarathi, R. (2014). Production and characterization of rhamnolipids produced by Serratia rubidaea SNAU02 under solid-state fermentation and its application as biocontrol agent. Bioresour. Technol. 173, 231-238. doi: 10.1016/j.biortech.2014.09.051

Nasir, M. N., Lins, L., Crowet, J. M., Ongena, M., Dorey, S., Dhondt-Cordelier, S., et al. (2017). Differential interaction of synthetic glycolipids with biomimetic plasma membrane lipids correlates with the plant biological response. Langmuir 33, 9979-9987. doi: 10.1021/acs.langmuir.7b01264

Naughton, P. J., Marchant, R., Naughton, V., and Banat, I. M. (2019). Microbial biosurfactants: current trends and applications in agricultural and biomedical industries. J. Appl. Microbiol. 127, 12-28. doi: 10.1111/jam.14243

Olorunleke, F. E., Hua, G. K. H., Kieu, N. P., Ma, Z., and Höfte, M. (2015). Interplay between orfamides, sessilins and phenazines in the control of Rhizoctonia diseases by Pseudomonas sp. CMR12a. Environ. Microbiol. Rep. 7, 774-781. doi: 10.1111/1758-2229.12310

Omoboye, O. O., Oni, F. E., Batool, H., Yimer, H. Z., De Mot, R., and Höfte, M. (2019). Pseudomonas cyclic lipopeptides suppress the rice blast fungus magnaporthe oryzae by induced resistance and direct antagonism. Front. Plant Sci. 10:901. doi: 10.3389/fpls.2019.00901

Ongena, M., and Jacques, P. (2008). Bacillus lipopeptides: versatile weapons for plant disease biocontrol. Trends Microbiol. 16, 115-125.

Ongena, M., Jourdan, E., Adam, A., Paquot, M., Brans, A., Joris, B., et al. (2007). Surfactin and fengycin lipopeptides of Bacillus subtilis as elicitors of induced systemic resistance in plants. Environ. Microbiol. 9, 1084-1090. doi: 10.1111/j. 1462-2920.2006.01202.x

Ortiz, A., Teruel, J. A., Espuny, M. J., Marqués, A., Manresa, Á, and Aranda, F. J. (2006). Effects of dirhamnolipid on the structural properties of phosphatidylcholine membranes. Intern. J. Pharm. 325, 99-107. doi: 10.1016/ j.ijpharm.2006.06.028

Otzen, D. E. (2017). Biosurfactants and surfactants interacting with membranes and proteins: same but different? Biochim. Biophys. Acta Biomemb. 1859, 639-649. doi: 10.1016/j.bbamem.2016.09.024

Penha, R. O., Vandenberghe, L. P. S., Faulds, C., Soccol, V. T., and Soccol, C. R. (2020). Bacillus lipopeptides as powerful pest control agents for a more sustainable and healthy agriculture: recent studies and innovations. Planta 251:70. doi: 10.1007/s00425-020-03357-7

Pérez-García, A., Romero, D., and de Vicente, A. (2011). Plant protection and growth stimulation by microorganisms: biotechnological applications of Bacilli in agriculture. Curr. Opin. Biotechnol. 22, 187-193. doi: 10.1016/j.copbio.2010. 12.003

Perneel, M., D’Hondt, L., De Maeyer, K., Adiobo, A., Rabaey, K., and Hofte, M. (2008). Phenazines and biosurfactants interact in the biological control of soil-borne diseases caused by Pythium spp. Environ. Microbiol. 10, 778-788.

Pieterse, C. M., Van der Does, D., Zamioudis, C., Leon-Reyes, A., and Van Wees, S. C. (2012). Hormonal modulation of plant immunity. Annu. Rev. Cell Dev. Biol. 28, 489-521. doi: 10.1146/annurev-cellbio-092910- 154055

Pieterse, C. M. J., Zamioudis, C., Berendsen, R. L., Weller, D. M., Wees, S. C. M. V., and Bakker, P. A. H. M. (2014). Induced systemic resistance by beneficial microbes. Annu. Rev. Phytopathol. 52, 347-375. doi: 10.1146/annurev-phyto082712-102340

Popp, J., Petö, K., and Nagy, J. (2013). Pesticide productivity and food security. A review. Agron. Sustain. Dev. 33, 243-255. doi: 10.1007/s13593-012-0105-x

Qi, G., Zhu, F., Du, P., Yang, X., Qiu, D., Yu, Z., et al. (2010). Lipopeptide induces apoptosis in fungal cells by a mitochondria-dependent pathway. Peptides 31, 1978-1986. doi: 10.1016/j.peptides.2010.08.003
Qian, S., Lu, H., Sun, J., Zhang, C., Zhao, H., Lu, F., et al. (2016). Antifungal activity mode of Aspergillus ochraceus by bacillomycin D and its inhibition of ochratoxin A (OTA) production in food samples. Food Control 60, 281-288. doi: 10.1016/j.foodcont.2015.08.006

Raaijmakers, J. M., De Bruijn, I., Nybroe, O., and Ongena, M. (2010). Natural functions of lipopeptides from Bacillus and Pseudomonas: more than surfactants and antibiotics. FEMS Microbiol. Rev. 34, 1037-1062. doi: 10.1111/ j.1574-6976.2010.00221.x

Rabbee, M. F., Ali, M. S., Choi, J., Hwang, B. S., Jeong, S. C., and Baek, K. H. (2019). Bacillus velezensis: a valuable member of bioactive molecules within plant microbiomes. Molecules 24:46. doi: 10.3390/molecules24061046

Rahman, A., Uddin, W., and Wenner, N. G. (2015). Induced systemic resistance responses in perennial ryegrass against Magnaporthe oryzae elicited by semipurified surfactin lipopeptides and live cells of Bacillus amyloliquefaciens. Mol. Plant Pathol. 16, 546-558. doi: 10.1111/mpp.12209

Rodrigues, A. I., Gudina, E. J., Teixeira, J. A., and Rodrigues, L. R. (2017). Sodium chloride effect on the aggregation behaviour of rhamnolipids and their antifungal activity. Sci. Rep. 7:12907. doi: 10.1038/s41598-017-13424-x

Rodríguez, J., Tonelli, M. L., Figueredo, M. S., Ibáñez, F., and Fabra, A. (2018). The lipopeptide surfactin triggers induced systemic resistance and priming state responses in Arachis hypogaea L. Eur. J. Plant Pathol. 152, 845-851. doi: 10. 1007/s10658-018-1524-6

Romero, D., de Vicente, A., Rakotoaly, R. H., Dufour, S. E., Veening, J.-W., Arrebola, E., et al. (2007). The Iturin and Fengycin families of lipopeptides are key factors in antagonism of Bacillus subtilis toward Podosphaera fusca. Mol. Plant Microb. Interact. 20, 430-440. doi: 10.1094/mpmi-20-4-0430

Sajid, M., Ahmad Khan, M. S., Singh Cameotra, S., and Safar Al-Thubiani, A. (2020). Biosurfactants: potential applications as immunomodulator drugs. Immunol. Lett. 223, 71-77. doi: 10.1016/j.imlet.2020.04.003

Sanchez, L., Courteaux, B., Hubert, J., Kauffmann, S., Renault, J. H., Clément, C., et al. (2012). Rhamnolipids elicit defense responses and induce disease resistance against biotrophic, hemibiotrophic, and necrotrophic pathogens that require different signaling pathways in Arabidopsis and highlight a central role for salicylic acid. Plant Physiol. 160, 1630-1641. doi: 10.1104/pp.112.201913

Sánchez, M., Aranda, F. J., Teruel, J. A., Espuny, M. J., Marqués, A., Manresa, Á, et al. (2010). Permeabilization of biological and artificial membranes by a bacterial dirhamnolipid produced by Pseudomonas aeruginosa. J. Coll. Interf. Sci. 341, 240-247. doi: 10.1016/j.jcis.2009.09.042

Sánchez, M., Aranda, F. J., Teruel, J. A., and Ortiz, A. (2009). Interaction of a bacterial dirhamnolipid with phosphatidylcholine membranes: a biophysical study. Chemi. Phys. Lipids 161, 51-55. doi: 10.1016/j.chemphyslip.2009. 06.145

Sánchez, M., Teruel, J. A., Espuny, M. J., Marqués, A., Aranda, F. J., Manresa, Á, et al. (2006). Modulation of the physical properties of dielaidoylphosphatidylethanolamine membranes by a dirhamnolipid biosurfactant produced by Pseudomonas aeruginosa. Chem. Phys. Lipids 142, 118-127. doi: 10.1016/j.chemphyslip.2006.04.001

Sathi Reddy, K., Yahya Khan, M., Archana, K., Gopal Reddy, M., and Hameeda, B. (2016). Utilization of mango kernel oil for the rhamnolipid production by Pseudomonas aeruginosa DR1 towards its application as biocontrol agent. Bioresour. Technol. 221, 291-299. doi: 10.1016/j.biortech.2016.09.041

Savary, S., Willocquet, L., Pethybridge, S. J., Esker, P., McRoberts, N., and Nelson, A. (2019). The global burden of pathogens and pests on major food crops. Nat. Ecol. Evol. 3, 430-439. doi: 10.1038/s41559-018-0793-y

Schellenberger, R., Touchard, M., Clement, C., Baillieul, F., Cordelier, S., Crouzet, J., et al. (2019). Apoplastic invasion patterns triggering plant immunity: plasma membrane sensing at the frontline. Mol. Plant Pathol. 20, 1602-1616. doi: 10.1111/mpp. 12857

Sen, S., Borah, S. N., Bora, A., and Deka, S. (2017). Production, characterization, and antifungal activity of a biosurfactant produced by Rhodotorula babjevae YS3. Microb. Cell Factor. 16:95. doi: 10.1186/s12934-017-0711-Z

Sha, R., Jiang, L., Meng, Q., Zhang, G., and Song, Z. (2012). Producing cellfree culture broth of rhamnolipids as a cost-effective fungicide against plant pathogens. J. Basic Microbiol. 52, 458-466. doi: 10.1002/jobm.201100295

Sha, R., and Meng, Q. (2016). Antifungal activity of rhamnolipids against dimorphic fungi. J. Gen. Appl. Microbiol. 62, 233-239. doi: 10.2323/jgam.2016. 04.004 
Sharma, A., Jansen, R., Nimtz, M., Johri, B. N., and Wray, V. (2007a). Rhamnolipids from the rhizosphere bacterium Pseudomonas sp. GRP(3) that reduces damping-off disease in Chilli and tomato nurseries. J. Nat. Products 70, 941-947. doi: 10.1021/np0700016

Sharma, A., Wray, V., and Johri, B. N. (2007b). Rhizosphere Pseudomonas sp. strains reduce occurrence of pre- and post-emergence damping-off in chile and tomato in Central Himalayan region. Archiv. Microbiol. 187, 321-335. doi: 10.1007/s00203-006-0197-2

Singh, P., and Cameotra, S. S. (2004). Potential applications of microbial surfactants in biomedical sciences. Trends Biotechnol. 22, 142-146. doi: 10. 1016/j.tibtech.2004.01.010

Singh, P., Patil, Y., and Rale, V. (2019). Biosurfactant production: emerging trends and promising strategies. J. Appl. Microbiol. 126, 2-13. doi: 10.1111/jam.14057

Stanghellini, M. E., and Miller, R. M. (1997). Biosurfactants : their identity and potential efficacy in the biological control of zoosporic plant pathogen. Plant Dis. 81, 4-12.

Straight, P. D., Willey, J. M., and Kolter, R. (2006). Interactions between Streptomyces coelicolor and Bacillus subtilis: role of surfactants in raising aerial structures. J. Bacteriol. 188, 4918-4925. doi: 10.1128/jb.00162-06

Syed Ab Rahman, S. F., Singh, E., Pieterse, C. M. J., and Schenk, P. M. (2018). Emerging microbial biocontrol strategies for plant pathogens. Plant Sci. 267, 102-111. doi: 10.1016/j.plantsci.2017.11.012

Takemoto, J., Bensaci, M., De Lucca, A., Cleveland, T., Gandhi, N., and Skebba, V. P. (2010). Inhibition of fungi from diseased grapeby syringomycin E-rhamnolipid mixture. Am. J. Enol. Viticu. 61, 120-124.

Tao, Y., Bie, X.-M., Lv, F.-X., Zhao, H.-Z., and Lu, Z.-X. (2011). Antifungal activity and mechanism of fengycin in the presence and absence of commercial surfactin against Rhizopus stolonifer. J. Microbiol. 49, 146-150. doi: 10.1007/ s12275-011-0171-9

Tran, H., Ficke, A., Asiimwe, T., Hofte, M., and Raaijmakers, J. M. (2007). Role of the cyclic lipopeptide massetolide A in biological control of Phytophthora infestans and in colonization of tomato plants by Pseudomonas fluorescens. New Phytol. 175, 731-742.

Varnier, A. L., Sanchez, L., Vatsa, P., Boudesocque, L., Garcia-Brugger, A., Rabenoelina, F., et al. (2009). Bacterial rhamnolipids are novel MAMPs conferring resistance to Botrytis cinerea in grapevine. Plant Cell Environ. 32, 178-193. doi: 10.1111/j.1365-3040.2008.01911.x

Vatsa, P., Sanchez, L., Clément, C., Baillieul, F., and Dorey, S. (2010). Rhamnolipid biosurfactants as new players in animal and plant defense against microbes. Intern. J. Mol. Sci. 11, 5095-5108.

Waewthongrak, W., Leelasuphakul, W., and McCollum, G. (2014). Cyclic LIPopeptides from Bacillus subtilis ABS-S14 elicit defense-related gene expression in citrus fruit. PLoS One 9:e109386. doi: 10.1371/journal.pone. 0109386

Wise, C., Falardeau, J., Hagberg, I., and Avis, T. J. (2014). Cellular lipid composition affects sensitivity of plant pathogens to fengycin, an antifungal compound produced by Bacillus subtilis strain CU12. Phytopathology 104, 1036-1041. doi: 10.1094/phyto-12-13-0336-r
Wu, L., Huang, Z., Li, X., Ma, L., Gu, Q., Wu, H., et al. (2018). Stomatal closure and SA-, JA/ET-signaling pathways are essential for Bacillus amyloliquefaciens FZB42 to restrict leaf disease caused by Phytophthora nicotianae in Nicotiana benthamiana. Front. Microbiol. 9:847. doi: 10.3389/fmicb.2018.00847

Xiu, P., Liu, R., Zhang, D., and Sun, C. (2017). Pumilacidin-like lipopeptides derived from marine bacterium Bacillus sp. strain 176 suppress the motility of Vibrio alginolyticus. Appl. Environ. Microbiol. 83:e00450-17. doi: 10.1128/aem. 00450- 17

Yamamoto, S., Shiraishi, S., and Suzuki, S. (2015). Are cyclic lipopeptides produced by Bacillus amyloliquefaciens S13-3 responsible for the plant defence response in strawberry against Colletotrichum gloeosporioides? Lett. Appl. Microbiol. 60, 379-386. doi: 10.1111/lam.12382

Yan, F., Xu, S., Chen, Y., and Zheng, X. (2014). Effect of rhamnolipids on Rhodotorula glutinis biocontrol of Alternaria alternata infection in cherry tomato fruit. Postharvest Biol. Technol. 97, 32-35. doi: 10.1016/j.postharvbio. 2014.05.017

Yan, F., Xu, S., Guo, J., Chen, Q., Meng, Q., and Zheng, X. (2015). Biocontrol of post-harvest Alternaria alternata decay of cherry tomatoes with rhamnolipids and possible mechanisms of action. J. Sci. Food Agric. 95, 1469-1474. doi: 10.1002/jsfa.6845

Yoo, D. S., Lee, B. S., and Kim, E. K. (2005). Characteristics of microbial biosurfactant as an antifungal agent against plant pathogenic fungus. J. Microbiol. Biotechnol. 15, 1164-1169.

Yoshida, S., Koitabashi, M., Nakamura, J., Fukuoka, T., Sakai, H., Abe, M., et al. (2015). Effects of biosurfactants, mannosylerythritol lipids, on the hydrophobicity of solid surfaces and infection behaviours of plant pathogenic fungi. J. Appl. Microbiol. 119, 215-224. doi: 10.1111/jam.12832

Zeriouh, H., Romero, D., García-Gutiérrez, L., Cazorla, F. M., de Vicente, A., and Pérez-García, A. (2011). The Iturin-like lipopeptides are essential components in the biological control arsenal of Bacillus subtilis against bacterial diseases of cucurbits. Mol. Plant Microb. Interact. 24, 1540-1552. doi: 10.1094/mpmi-0611-0162

Zhong, H., Yang, L., Yang, X., Zeng, G., Liu, Z., Liu, Y., et al. (2015). Aggregation of low-concentration dirhamnolipid biosurfactant in electrolyte solution. RSC $A d v$. 5, 88578-88582. doi: 10.1039/C5RA1 6817A

Conflict of Interest: The authors declare that the research was conducted in the absence of any commercial or financial relationships that could be construed as a potential conflict of interest.

Copyright (C) 2020 Crouzet, Arguelles-Arias, Dhondt-Cordelier, Cordelier, Pršić, Hoff, Mazeyrat-Gourbeyre, Baillieul, Clément, Ongena and Dorey. This is an open-access article distributed under the terms of the Creative Commons Attribution License (CC BY). The use, distribution or reproduction in other forums is permitted, provided the original author(s) and the copyright owner(s) are credited and that the original publication in this journal is cited, in accordance with accepted academic practice. No use, distribution or reproduction is permitted which does not comply with these terms. 